\title{
Synthesis, in vitro and in vivo biological evaluation, COX-1/2 inhibition and molecular docking study of indole- $N$-acylhydrazone derivatives
}

\author{
Ana Daura Travassos de Oliveira Moraes ${ }^{a}$, Mirelly Dianne Santos de Miranda ${ }^{\mathrm{a}}$, \\ Íris Trindade Tenório Jacob ${ }^{\mathrm{a}}$, Cézar Augusto da Cruz Amorim ${ }^{\mathrm{a}}$, Ricardo Olímpio de Moura ${ }^{\mathrm{b}}$, \\ Simone Ângela Soares da Silva ${ }^{\mathrm{b}}$, Milena Botelho Pereira Soares ${ }^{\mathrm{c}}$, \\ Sinara Mônica Vitalino de Almeida ${ }^{\mathrm{d}}$, Túlio Ricardo Couto de Lima Souza ${ }^{\mathrm{e}}$, \\ Jamerson Ferreira de Oliveira ${ }^{a}$, Teresinha Gonçalves da Silva ${ }^{a}$, \\ Cristiane Moutinho Lagos de Melo ${ }^{a}$, Diogo Rodrigo Magalhães Moreira ${ }^{c}$, \\ Maria do Carmo Alves de Lima ${ }^{\mathrm{a}}$, \\ ${ }^{\text {a }}$ Universidade Federal de Pernambuco (UFPE), Departamento de Antibióticos (DANTI), 50670-901 Recife, PE, Brazil

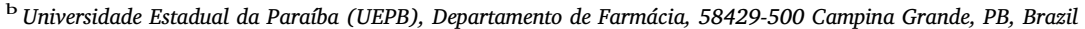 \\ ${ }^{\mathrm{c}}$ Fundação Oswaldo Cruz, Centro de Pesquisa Gonçalo Moniz/Laboratório de Engenharia Tecidual e Imunofarmacologia, 40296-710 Salvador, BA, Brazil \\ d Universidade de Pernambuco (UPE), Faculdade de Ciências, Educação e Tecnologia de Garanhuns (FACETEG), 55290-000 Garanhuns, PE, Brazil \\ ${ }^{\text {e }}$ Universidade Federal Rural de Pernambuco (UFRPE), Unidade Acadêmica de Serra Talhada (UAST), 56909-535 Serra Talhada, PE, Brazil
}

\section{A R T I C L E I N F O}

\section{Keywords:}

Inflammation

$N$-Acylhydrazones

Indoles

COX

Docking

\begin{abstract}
A B S T R A C T
The objective of this work was to obtain and evaluate anti-inflammatory in vitro, in vivo and in silico potential of novel indole- $N$-acylhydrazone derivatives. In total, 10 new compounds $(\mathbf{3 a} \mathbf{a} \mathbf{j})$ were synthesized in satisfactory yields, through a condensation reaction in a single synthesis step. In the lymphoproliferation assay, using mice splenocytes, 3a and $\mathbf{3 b}$ showed inhibition of lymphocyte proliferation of $62.7 \%( \pm 3.5)$ and $50.7 \%( \pm 2)$, respectively, while dexamethasone presented an inhibition of $74.6 \%( \pm 2.4)$. Moreover, compound $3 \mathrm{~b}$ induced higher Th2 cytokines production in mice splenocytes cultures. The results for COX inhibition assays showed that compound $\mathbf{3 b}$ is a selective COX-2 inhibitor, but with less potency when compared to celecoxib, and compound 3a not presented selectivity towards COX-2. The molecular docking results suggest compounds $\mathbf{3 a}$ and $\mathbf{3 b}$ interact with the active site of COX-2 in similar conformations, but not with the active site of COX-1, and this may be the main reason to the COX-2 selectivity of compound $3 \mathbf{b}$. In vivo carrageenan-induced paw edema assays were adopted for the confirmation of the anti-inflammatory activity. Compound $\mathbf{3 b}$ showed better results in suppressing edema at all tested concentrations and was able to induce an edema inhibition of $100 \%$ after $5 \mathrm{~h}$ of carrageenan injection at the $30 \mathrm{mg} \mathrm{kg}^{-1}$ dosage, corroborating with the COX inhibition and lymphoproliferation results. I addition to our experimental results, in silico analysis suggest that compounds $\mathbf{3 a}$ and $\mathbf{3 b}$ present a wellbalanced profile between pharmacodynamics and pharmacokinetics. Thus, our preliminary results revealed the potentiality of a new COX-2 selective derivative in the modulation of the inflammatory process.
\end{abstract}

\section{Introduction}

Inflammation is a protective response of the body initiated after infection or injury. This process is accomplished by a sequence of events involving molecular, cellular and physiological modifications. In addition, there is an involvement of mediators such as cytokines, free radicals, vasoactive amines and eicosanoids (mainly prostaglandins) produced by cells such as macrophages, lymphocytes, mast cells and fibroblasts. ${ }^{1}$
In relation to prostaglandins, they stem from the conversion of arachidonic acid by enzymes called cyclooxygenases (COXs). ${ }^{2}$ Two isoforms are well known in cyclooxygenase, COX-1 and COX-2. COX-1 is present in most normal tissues or cells, whereas COX-2 is practically absent, but induced during inflammatory processes and responsible for increased prostaglandin synthesis. ${ }^{3}$ These enzymes are inhibited by non-steroids anti-inflammatory drugs (NSAIDs). ${ }^{4}$ However, inhibition of the constitutive isoform (COX-1) has been associated with side effects

\footnotetext{
* Corresponding author.

E-mail address: nenalima.mariadocarmo@gmail.com (M.d.C.A.d. Lima).
} 
of this drug class, mainly gastrointestinal effects. ${ }^{5}$ Thus, the development of more specific drugs and with fewer adverse effects has been the object of study in the medicinal chemistry research area.

In this context, $\mathrm{N}$-acylhydrazones and indoles can be considered privileged structures for the design of bioactive compounds with antiinflammatory activity. ${ }^{6,7}$ The literature describes the anti-inflammatory activity of $N$-acylhydrazones when conjugated to heterocycle nuclei such as furanoxyl, ${ }^{8}$ pyrazine $^{7}$ and 1,3-benzodioxole. ${ }^{9}$ Additionally, indoles are reported as inhibitors of important targets involved in the inflammatory process such as COX- $2,{ }^{10}$ phospholipase $\mathrm{A} 2{ }^{11}$ and cytokines such as IL- $1 \beta$ and TNF- $\alpha{ }^{12}$

In previous studies conducted by our research group, molecules bearing the indole heterocycle conjugated to other important pharmacophores such as thiazolidine and imidazolidine were able to inhibit lymphoproliferation, reduce expression/production of COX-2, IL-1 $\beta$ and TNF, and showed a good pharmacokinetic profile. ${ }^{12-15}$ Thus, in view of these evidences that prove the biological importance of $N$ acylhydrazones and indoles in medicinal chemistry, in this work we aimed to synthesize new molecules containing these conjugated privileged structures, as well as to evaluate the in vivo and in vitro antiinflammatory activity and the COX-1/2 inhibition profile of these new compounds.

\section{Results and discussion}

\subsection{Chemistry}

Compounds of interest in this study $(\mathbf{3} \mathbf{a}-\mathbf{j})$ were obtained by employing a condensation reaction between equimolar amounts of the cyanoacetohydrazide and different 3-indole carboxaldehydes moieties. The reaction occurred under acid catalysis, to form the oxonium ion (carboxaldehyde) that later undergo nucleophilic attack of the hydrazide nitrogen. This was followed by the elimination of water with formation of $N$-acylhydrazone. ${ }^{16}$ The employed route (Scheme 1 ) was adequate since the reaction yield ranged between 61 and $98 \%$.

All compounds were characterised by NMR and IR spectroscopy and the spectral data was consistent with the proposed structures. In all IR spectra, absorption peaks in the $1667-1684 \mathrm{~cm}^{-1}$ range, characteristic of the carbonyl group $(\mathrm{C}=\mathrm{O})$, were observed. In addition, bands in the region $2223-2279 \mathrm{~cm}^{-1}$ and $3145-3332 \mathrm{~cm}^{-1}$ were assigned to the nitrile $(\mathrm{CN})$ and amine $(-\mathrm{NH}-)$ functions, respectively. As a characteristic point in IR spectroscopy, we can highlight the appearance of the absorption band in the range of $1580-1621 \mathrm{~cm}^{-1}$ corresponding to the imine function $(\mathrm{C}=\mathrm{N})$. All the absorption bands and characteristic stretches are in agreement with the literature. ${ }^{17,18}$

In the ${ }^{1} \mathrm{H}$ NMR spectra of compounds $\mathbf{3 a}-\mathbf{j}$, singlets relative to the azomethine hydrogen between 8.16 and $8.51 \mathrm{ppm}$ confirmed the success of the condensation reaction. The formation of imines from primary amines and carbonyl compounds has been extensively investigated in the field of medicinal chemistry due to their biological importance. ${ }^{17-19}$ The hydrogens in the $\mathrm{CH}_{2}$ group were observed as a

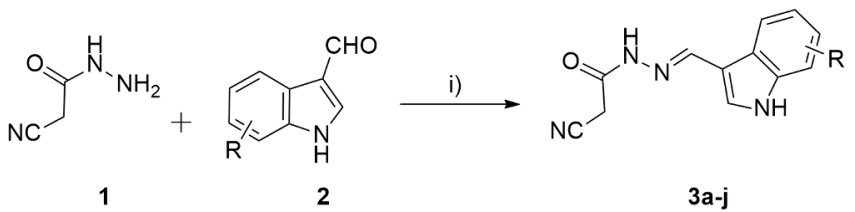
3a 5-bromo-indole $3 \mathrm{~b}$ indole
3c 5-methyl-indole
3d 4-nitro-indole
$3 f$ benzo[g]-indole
3g 7-methyl-indole
3h 5-cyano-indole
3i pyrrolo[2,3-b]pyridin-indole
3e 5-methoxy-indole 3 j 5-chloro-indole

Scheme 1. Synthesis of indole- $N$-acylhydrazones (3a-j) derivatives. Reagents and conditions: (i) $\mathrm{AcOH}$ (few drops), $\mathrm{EtOH}$, room temperature. singlet peak between 4.10 and $4.30 \mathrm{ppm}$. It was also possible to identify the indole hydrogen ( $\mathrm{NH})$ as a singlet in the range of $11.43-11.60 \mathrm{ppm}$. In addition, the other hydrogens related to this heterocycle were observed in the region between 6.83 and $8.47 \mathrm{ppm}$ as singlets, doublets and triplets.

$\mathrm{N}$-acylhydrazones can be obtained in two diastereomeric configurations $(Z / E)$. Cordeiro et al. $(2016)^{20}$ stated in their work that the absence of duplicity in the imine and amide hydrogen signals is an indicative of the presence of a single diastereomer. In this study, the $\mathbf{3 b}$ molecule was chosen to elucidate the diastereomeric configuration of the derivatives in this series. The duplication of the signals at $\delta 8.20$ (imine) and $\delta 11.45$ (amide) (signals of greater intensity) at $\delta 8.35$ (imine) and $\delta 11.36$ (amide) (signals of lower intensity) was observed, showing a ratio of $76: 24$, confirming that it is a mixture of diastereoisomers.

To assign the configuration of the major diastereomer, a NOESY experiment was performed and a spatial correlation was observed between the hydrogens $\delta 8.20$ (imine) and 11.45 (amide). In addition, a spatial correlation was observed between the hydrogens $\delta 7.80$ (at C2indole) and 8.20 (imine), which corresponds to the $Z$-isomer as a major in our synthesis. Thus, the ratio of the diastereoisomers formed in this study was 76:24 $(Z / E)$. Studies have shown preference for the $E$ configuration of $N$-acylhydrazones ${ }^{21}$ even when obtained as a mixture of diastereomers. ${ }^{22}$ However, our study showed the opposite, exhibited a higher preference for the $Z$ isomer.

\subsection{Anti-inflammatory activity}

\subsubsection{Cytotoxicity and lymphoproliferation assays}

After the synthesis of the new indole- $N$-acylhydrazone derivatives, the in vitro cytotoxic profile of the compounds was evaluated against macrophages of the J774 line. It was verified that the most part of derivatives presented a low cytotoxicity against this cellular line when compared to gentian violet, the control used in the experiment, which showed a cytotoxicity of $4.2 \pm 0.6 \mu \mathrm{M}$ (Table 1 ). $\mathbf{3 a}, \mathbf{3 b}, \mathbf{3} \mathbf{c}$ and $\mathbf{3 g}$ presented $\mathrm{CC}_{50}$ values of $144 \pm 63,150.1 \pm 40,200 \pm 22$ and $145.5 \pm 23 \mu \mathrm{M}$, respectively. The $N$-acylhydrazone derivatives are known for their remarkable biological activity and low cytotoxicity, which leads to greater biological selectivity. ${ }^{23,24}$

In addition, in vitro screening of the anti-inflammatory potential was also performed by a lymphoproliferation assay (Table 1 ). This study allows to indicate the percentage inhibition of the T lymphocytes proliferation induced by concanavalin $\mathrm{A}^{25}$, where the highest percentage of inhibition reveals an increased anti-inflammatory activity through an immunosuppressive action. Table 1 shows the percentual results of lymphoproliferation inhibition at $50 \mu \mathrm{M}$ concentration. It is possible to highlight that compounds $3 \mathrm{a}, \mathbf{3 b}, \mathbf{3} \mathbf{g}$ and $3 \mathbf{i}$ presented values of $62.7 \%$ ( \pm 3.5), $50.7 \%( \pm 2), 52.2 \%( \pm 1.8)$ and $52.4 \%( \pm 19.1)$ inhibition, respectively, while dexamethasone - positive control - presented an

Table 1

Inhibitory activity of the new indole- $N$-acylhydrazone derivatives tested against splenocyte proliferation and cytotoxicity in macrophages J774.

\begin{tabular}{lll}
\hline Compound & $\begin{array}{l}\text { \% lymphoproliferation } \\
\text { inhibition } \pm \text { SEM }(50 \mu \mathrm{M})\end{array}$ & $\begin{array}{l}\text { Citotoxicity }\left(\mathrm{CC}_{50}\right) \\
\mu \mathrm{M} \pm \mathrm{SEM}\end{array}$ \\
\hline $\mathbf{3 a}$ & $62.7 \pm 3.5$ & $144 \pm 63$ \\
$\mathbf{3 b}$ & $50.7 \pm 2$ & $150.1 \pm 40$ \\
$\mathbf{3 c}$ & $15.4 \pm 0.3$ & $200 \pm 22$ \\
$\mathbf{3 d}$ & $31 \pm 1.8$ & $66 \pm 7$ \\
$\mathbf{3 e}$ & $43.7 \pm 0.8$ & $101 \pm 14$ \\
$\mathbf{3 f}$ & $1.2 \pm 0.2$ & $78.5 \pm 11$ \\
$\mathbf{3 g}$ & $52.2 \pm 1.8$ & $145.5 \pm 23$ \\
$\mathbf{3 h}$ & $25.7 \pm 5.4$ & $69.4 \pm 17$ \\
$\mathbf{3 i}$ & $52.4 \pm 19.1$ & $107 \pm 21$ \\
$\mathbf{3 j}$ & $1.8 \pm 0.2$ & $76.9 \pm 10$ \\
Dexamethasone & $74.6 \pm 2.4$ & -
\end{tabular}


inhibition of $74.6 \%( \pm 2.4)$. The inhibition of lymphocyte proliferation is indicative of anti-inflammatory action in the early-stage of the proccess. Based on these results, two compounds were selected for further studies on anti-inflammatory activity, $\mathbf{3 a}$ and $\mathbf{3} \mathbf{b}$. The latter compound was chosen due to the absence of substitution on the heterocycle ring (3a-5-bromoindole; $\mathbf{3 b}$-indole without substitution) and its low cytotoxicity.

In our study, the structural differences presented by the compounds are evidenced in the indole nucleus. This heterocycle has substitutions by electron withdrawing groups and donors. However, such effects do not appear to be directly related to the results found in the lymphoproliferation assay. For example, the compounds $\mathbf{3 a}$ and $\mathbf{3} \mathbf{j}$ are replaced by the bromine and chlorine atoms, respectively. However, the results presented by these compounds were opposite where $\mathbf{3 a}$ and $\mathbf{3} \mathbf{j}$ showed percent inhibition of lymphoproliferation of 62.7 and $1.8 \%$, respectively. The same results could also be observed in the inclusion of electron donor groups (methyl groups - compounds $\mathbf{3 c}$ and $\mathbf{3 g}$ ), where the results presented by these compounds were, respectively, 15.4 and $52.2 \%$.

2.2.2. Th2 cytokines and low nitric oxide production promoted by compound $\mathbf{3 b}$ in mice splenocytes cultures

Compound $\mathbf{3 b}$ induced higher Th2 cytokines production, in mice splenocytes, in $24 \mathrm{~h}$ and $48 \mathrm{~h}$ of incubation. Results are showed in Fig. 1A-F. The high production of IL-4 and IL-10 cytokines besides to low production of IFN- $\gamma$ are indicators of anti-inflammatory status promoted by compound $\mathbf{3 b}$. Moreover, the low production of the IFN- $\gamma$ also induced low release of nitric oxide, a key mediator of inflammatory response (Fig. 2). Freitas et al. (2018) ${ }^{26}$ found similar results in theirs studies with new naphthyl- $N$-acylhydrazone derivatives. These authors showed high anti-inflammatory profile promoted by compound associated with low TNF- $\alpha$ production. Moreover, Silva et al. (2015) ${ }^{27}$ investigating a new class of cycloalkyl analogues, also showed potential anti-inflammatory and analgesic activity in these compounds.

A

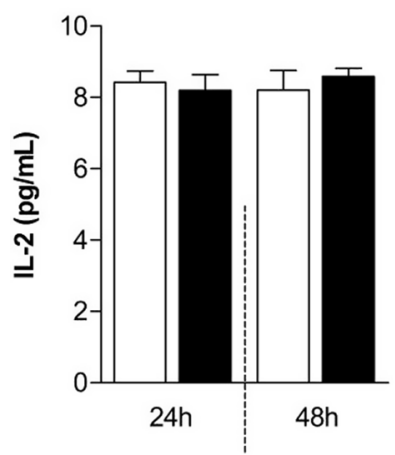

D

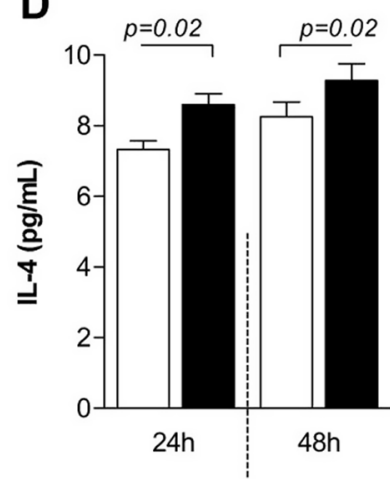

B

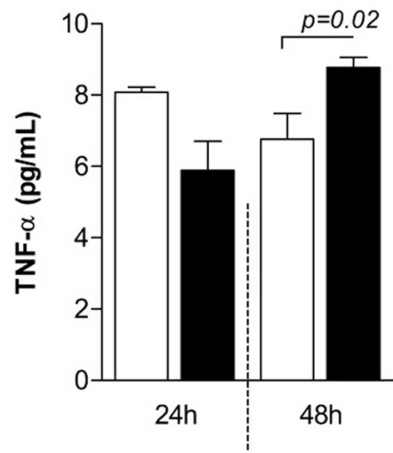

E

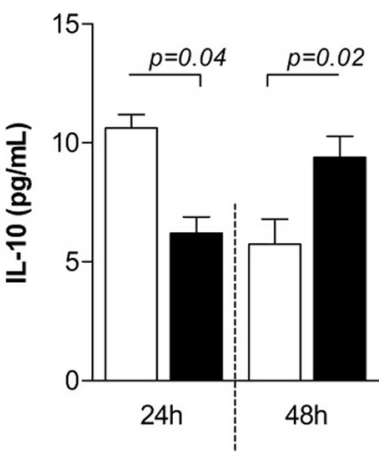

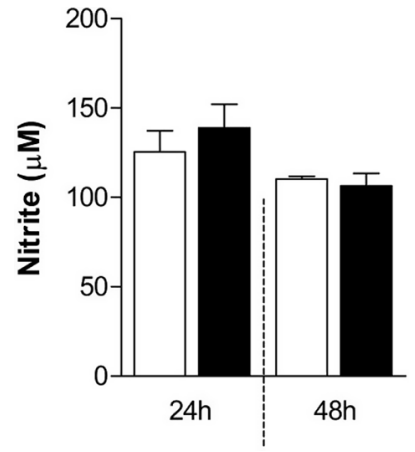

Fig. 2. Nitric oxide production by splenocytes treated with $11 \mu \mathrm{M}$ of compound 3b. Like control (cells + culture medium) nitric oxide was produced in basal levels in both experimental times. With vertical bars represents control samples (cells + cultures medium) and black vertical bars represent cells treated. Two independent experiments were performed in triplicate.

\subsubsection{Acute oral toxicity single dose}

Oral administration of compounds $\mathbf{3 a}$ and $\mathbf{3} \mathbf{b}$ did not lead to significant toxic effects at the high tested concentration of $2000 \mathrm{mg} \mathrm{kg}^{-1}$, as recommended by OECD (2002). ${ }^{28}$ After $1 \mathrm{~h}$ of administration of the test compounds, irritability and ptosis were observed. However, throughout the experiment until completion, no death or change in physiological parameters and hematological parameters were observed as demonstated in supplementary material. Based on these results, the in vivo anti-inflammatory assay was conducted at 15,30 , and $60 \mathrm{mg} \mathrm{kg}^{-1}$ doses for compounds $\mathbf{3 a}$ and $\mathbf{3 b}$.

\subsubsection{Carrageenan-induced paw edema}

For the in vivo evaluation of the selected compounds, the experimental model of carrageenan-induced paw edema was used, which is a widely employed assay to evaluate anti-inflammatory effects of new compounds. ${ }^{29}$ The results of this assay are described in Table 2.
C

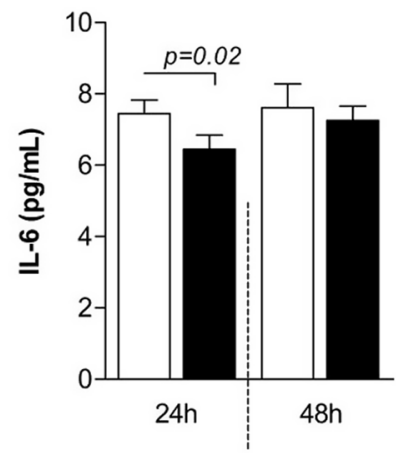

$\mathbf{F}$

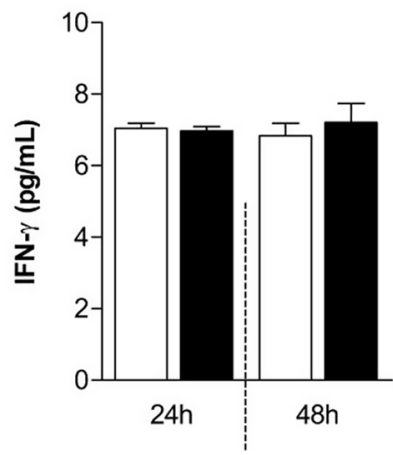

Fig. 1. Cytokines production in cultures of mice splenocytes treated with compound $\mathbf{3 b}$ at $11 \mu \mathrm{M}$. A to E: IL-2, TNF- $\alpha$, IL-6, IL4, IL10 and IFN- $\gamma$ cytokines. Compound $\mathbf{3 b}$ was not able to promote significant production of the IL-2 (A) and IFN- $\gamma$ (F) cytokines. However, in $24 \mathrm{~h}$ of assay, IL- 6 was produced in higher values and in $48 \mathrm{~h}$ TNF- $\alpha$ also was produced in higher values by splenocytes. IL-4 (D) and IL-10 (E) cytokines were produced in higher values in both experimental times proving the anti-inflammatory profile of $\mathbf{3 b}$. With vertical bars represents control samples (cells + cultures medium) and black vertical bars represent cells treated. Two independent experiments were performed in triplicate. 
Table 2

Anti-inflammatory effect of the indole- $N$-acylhydrazone derivatives after carrageenan-induced paw edema assay.

\begin{tabular}{|c|c|c|c|c|c|c|c|c|}
\hline \multirow[t]{2}{*}{ Time (h) } & \multirow[t]{2}{*}{ Negative control } & \multirow{2}{*}{$\frac{\text { Indomethacin }}{10 \mathrm{mg} \cdot \mathrm{kg}^{-1}}$} & \multicolumn{3}{|l|}{ Derivative 3a } & \multicolumn{3}{|l|}{ Derivative $\mathbf{3 b}$} \\
\hline & & & $15 \mathrm{mg} \cdot \mathrm{kg}^{-1}$ & $30 \mathrm{mg} \cdot \mathrm{kg}^{-1}$ & $60 \mathrm{mg} \cdot \mathrm{kg}^{-1}$ & $15 \mathrm{mg} \cdot \mathrm{kg}^{-1}$ & $30 \mathrm{mg} \cdot \mathrm{kg}^{-1}$ & $60 \mathrm{mg} \cdot \mathrm{kg}^{-1}$ \\
\hline 1 & $59.39 \pm 10.59$ & $19.06 \pm 3.59^{\text {**ke }}$ & $65.95 \pm 12.61$ & $50.00 \pm 0.02$ & $48.33 \pm 1.66$ & $25.00 \pm 7.75^{* k * k}$ & $6.60 \pm 1.51^{* * * *}$ & $15.23 \pm 3.60^{* * * * *}$ \\
\hline 2 & $63.09 \pm 7.32$ & $17.39 \pm 3.27^{\text {**k*k}}$ & $54.38 \pm 6.44$ & $50.96 \pm 5.91$ & $54.16 \pm 5.08$ & $31.41 \pm 8.52^{\text {k.kk }}$ & $8.77 \pm 4.05^{\text {*.*. }}$ & $22.50 \pm 5.35^{\text {k***** }}$ \\
\hline 3 & $43.53 \pm 5.06$ & $17.39 \pm 3.27^{* * *}$ & $43.23 \pm 4.49$ & $41.97 \pm 4.01$ & $49.33 \pm 2.35$ & $29.51 \pm 15.12$ & $3.63 \pm 2.29^{k \text { k**kx}}$ & $18.17 \pm 7.21^{*}$ \\
\hline 4 & $48.95 \pm 6.59$ & $24.51 \pm 4.87^{* *}$ & $41.90 \pm 3.73$ & $29.12 \pm 6.16^{*}$ & $29.38 \pm 4.62$ & $41.60 \pm 8.48$ & $2.25 \pm 1.14^{* * * *}$ & $21.66 \pm 6.19^{\text {k****}}$ \\
\hline 5 & $52.03 \pm 6.53$ & $12.57 \pm 3.67^{\text {**kk }}$ & $40.57 \pm 4.63$ & $24.83 \pm 4.08^{* * k}$ & $23.19 \pm 4.06^{k * * *}$ & $28.96 \pm 16.84$ & $0.00 \pm 0.00^{\text {**** }}$ & $8.00 \pm 5.33^{\text {***k*k}}$ \\
\hline 6 & $56.13 \pm 7.17$ & $8.93 \pm 2.87^{* * * k}$ & $35.23 \pm 7.61$ & $21.42 \pm 2.91^{\text {k.k.k. }}$ & $18.90 \pm 3.62^{k * * k}$ & $18.53 \pm 7.60^{\text {*..k\%k }}$ & $0.00 \pm 0.00^{\text {****k }}$ & $4.19 \pm 2.83^{\text {w**k }}$ \\
\hline
\end{tabular}

Data were expressed as the mean $\pm \mathrm{SE}$ of 6 animals per group. Results were considered significant when ${ }^{*} \mathrm{p}<0.05$; $^{* * *} \mathrm{p}<0.01$ and ${ }^{* * * *} \mathrm{p}<0.001$ (in comparison to negative control group), determined by analysis of variance (ANOVA) followed by Bonferroni posttests.

Compound 3a showed moderate anti-inflammatory activity at doses of 30 and $60 \mathrm{mg} \mathrm{kg}^{-1}$, where it caused an edema suppression of 61.82 and $66.32 \%$, respectively, after $6 \mathrm{~h}$ of carrageenan inoculation. In addition, the dose of $15 \mathrm{mg} \mathrm{kg}^{-1}$ did not cause significant edema inhibition in any of the evaluated times.

On the other hand, all the doses tested for the compound $\mathbf{3 b}$ presented significant values of paw edema inhibition, emphasizing the doses of 30 and $60 \mathrm{mg} \mathrm{kg}^{-1}$, which caused significant inhibition in all evaluated times. After $1 \mathrm{~h}, \mathbf{3 b}$ promoted $88.87 \%$ inhibition and after $5 \mathrm{~h}, 100 \%$, at the dose of $30 \mathrm{mg} \mathrm{kg}^{-1}$. At the $60 \mathrm{mg} \mathrm{kg}^{-1}$ dose, the best results were found after $1 \mathrm{~h}$ of administration (74.34\% inhibition) and $6 \mathrm{~h}\left(92.53 \%\right.$ inhibition). The dose of $15 \mathrm{mg} \mathrm{kg}^{-1}$ showed better results after $6 \mathrm{~h}$ of inoculation of the phlogistic agent (66.97\% inhibition). Indomethacin $\left(10 \mathrm{mg} \mathrm{kg}^{-1}\right)$, the standard drug used in the experiment, also showed significant results at all time points, with an inhibition of $72.43 \%$ and $84.07 \%$ at $2 \mathrm{~h}$ and $6 \mathrm{~h}$, repectively.

Carrageenan-induced inflammation is a biphasic process where the release of mediators such as serotonin, histamine, kinins, nitric oxide, and prostaglandins from neutrophil recruitment initiates. The first phase occurs up to $2 \mathrm{~h}$ after the phlogistic agent injection, while the late phase (cell phase) occurs up to $6 \mathrm{~h}$ after the administration of carrageenan. ${ }^{30,31}$ These results indicate a possible action of $\mathbf{3 b}$ in the inhibition of vasoactive amines, preventing the degranulation of mast cells, and in the cellular phase, inhibiting lymphocyte migration, a fact supported by the results in the lymphoproliferation assay. The fact that the model of paw edema carrageenan-induced consists of a biphasic process may justify our results not being dose-dependent or time-dependent. This evidence is valid since different mediators of the inflammatory process are acting in this murine model.

The compounds evaluated in this study present two privileged groups, the $\mathrm{N}$-acylhydrazone moiety and the indole heterocycle. $\mathrm{N}$ acylhydrazones are well described in the literature as anti-inflammatory agents ${ }^{9,32,33}$ and the indole heteroaromatic group was related to the maximal anti-inflammatory response in a carrageenan-induced paw edema assay, as described by Bhookya et al. (2017). ${ }^{34}$ In addition, the pharmacologic potential of hydrazone-indole compounds has been reported in models of acute and chronic inflammation ${ }^{35}$, which highlights the importance of these nuclei for the development of anti-inflammatory activity.

\subsubsection{Cyclooxygenase (1 and 2) in vitro inhibition assay}

In order to evaluate the COX inhibition profiles of the compounds in this study, in vitro COX-1 and COX-2 inhibition tests were carried out with compounds $\mathbf{3 a}$ and $\mathbf{3 b}$ (from 1.5 to $100 \mu \mathrm{M}$ ) to determine the concentration produced $50 \%$ inhibition of enzymes $\left(\mathrm{IC}_{50}\right)$ and their selectivity indices (SI) using celecoxib as reference drug. The results show that both compounds $\mathbf{3 a}$ and $\mathbf{3 b}$ were able to inhibit both COX-1 and COX-2 at low concentrations (Table 3 ). In relation of selectivity index (SI), only compound $\mathbf{3 b}$ displayed COX-2 inhibitory activity (SI: 1.51), but with less potency when compared to celecoxib (SI: 11.88).

The interaction test with enzymes and potential inhibitors is an
Table 3

In vitro COX-1 and COX-2 inhibition and COX-2SI of new indole- $N$-acylhydrazone derivatives (3a and $\mathbf{3 b}$ ).

\begin{tabular}{llll}
\hline Compound & \multicolumn{2}{c}{$\mathrm{IC}_{50}(\mu \mathrm{M})^{\mathrm{a}}$} & \multicolumn{2}{c}{$\mathrm{SI}^{\mathrm{b}}$} \\
\cline { 2 - 3 } & $\mathrm{COX}-1$ & $\mathrm{COX}-2$ & 0.72 \\
\hline 3a & 0.18 & 0.25 & 1.51 \\
3b & 1.54 & 1.02 & 11.88 \\
\hline Celecoxib & 3.09 & 0.26 & \\
\hline
\end{tabular}

${ }^{\mathrm{a}} \mathrm{IC}_{50}$ value is the compound concentration required to produce $50 \%$ inhibition of COX-1 or COX-2 for means of three determinations.

${ }^{\text {b }} \mathrm{SI}$ : ratio $\left(\mathrm{IC}_{50} \mathrm{COX}-1 / \mathrm{IC}_{50} \mathrm{COX}-2\right)$.

important step in the development of potential anti-inflammatory drugs. Knowledge of the structural differences between pharmacological targets is essential for the design of new active substances with greater specificity. In this context, the main difference between COX-1 and COX-2 is the higher COX-2 active site volume compared to COX-1 (about 20\%). ${ }^{36}$

\subsubsection{In silico studies of $C O X-1$ and $C O X-2$ interactions}

In order to better understand the COX selectivity of $\mathbf{3 a}$ and $\mathbf{3 b}$, a docking study was performed between these compounds and both COX isoenzymes. For this purpose, two celecoxib co-crystallized models for COX-1 and COX-2 (PDB codes: 3KK6 and 3LN1, respectively) were selected as targets since celecoxib is used as a reference compound for our in vitro COX inhibition assays. In the first step of the procedure, celecoxib was redocked into the active site of COX-1 and COX-2 with a binding free energy of -10.62 and $-10.80 \mathrm{kcal} \mathrm{mol}^{-1}$, respectively. Docking of test compounds showed that they can occupy the same binding site as the co-crystallized ligand. Compounds $\mathbf{3 a}$ and $\mathbf{3 b}$ bind to COX-1 enzyme by releasing free energy of -8.28 and $-7.84 \mathrm{kcal} \mathrm{mol}^{-1}$, respectively, and to COX-2 releasing free energy of -8.52 and $-7.73 \mathrm{kcal} \mathrm{mol}^{-1}$, respectively. Docking poses of compounds $\mathbf{3 a}$ and $\mathbf{3 b}$ at COX-1 and COX-2 active sites are shown in Fig. 3.

The presence of the volumous bromine atom in compound $\mathbf{3 a}$ leads to different conformations between these compounds at the COX active sites. At the COX-2 active site, the main difference between the docked conformations is the indole ring position. Compound $\mathbf{3 b}$, which presented in vitro COX-2 selectivity, interacts with COX-2 at Ile503 and Phe504 via hydrogen bonds to the nitrile function. The indole rings interact with Met508 via Pi-Sulfur and Amide-Pi stacking interactions, and forms amide-pi stacking interactions with Gly512. The indole ring of compound 3a assumes a different conformation in order to fit the hydrophobic pocket of the COX-2 active site, and interacts with 4 aminoacids (Leu338, Ala513, Val335, Va1509) via Pi-Alkyl interactions. Compound 3a also interacts with COX-2 Ile503 and Phe504 via hydrogen bonds to the carbonyl, and with Arg 499 via one hydrogen bond to the nitrile.

The obtained docking poses for COX-1 show $\mathbf{3 a}$ and $\mathbf{3 b}$ at distinct conformations. At the less volumous active site of COX-1, $\mathbf{3 b}$ assumes a 


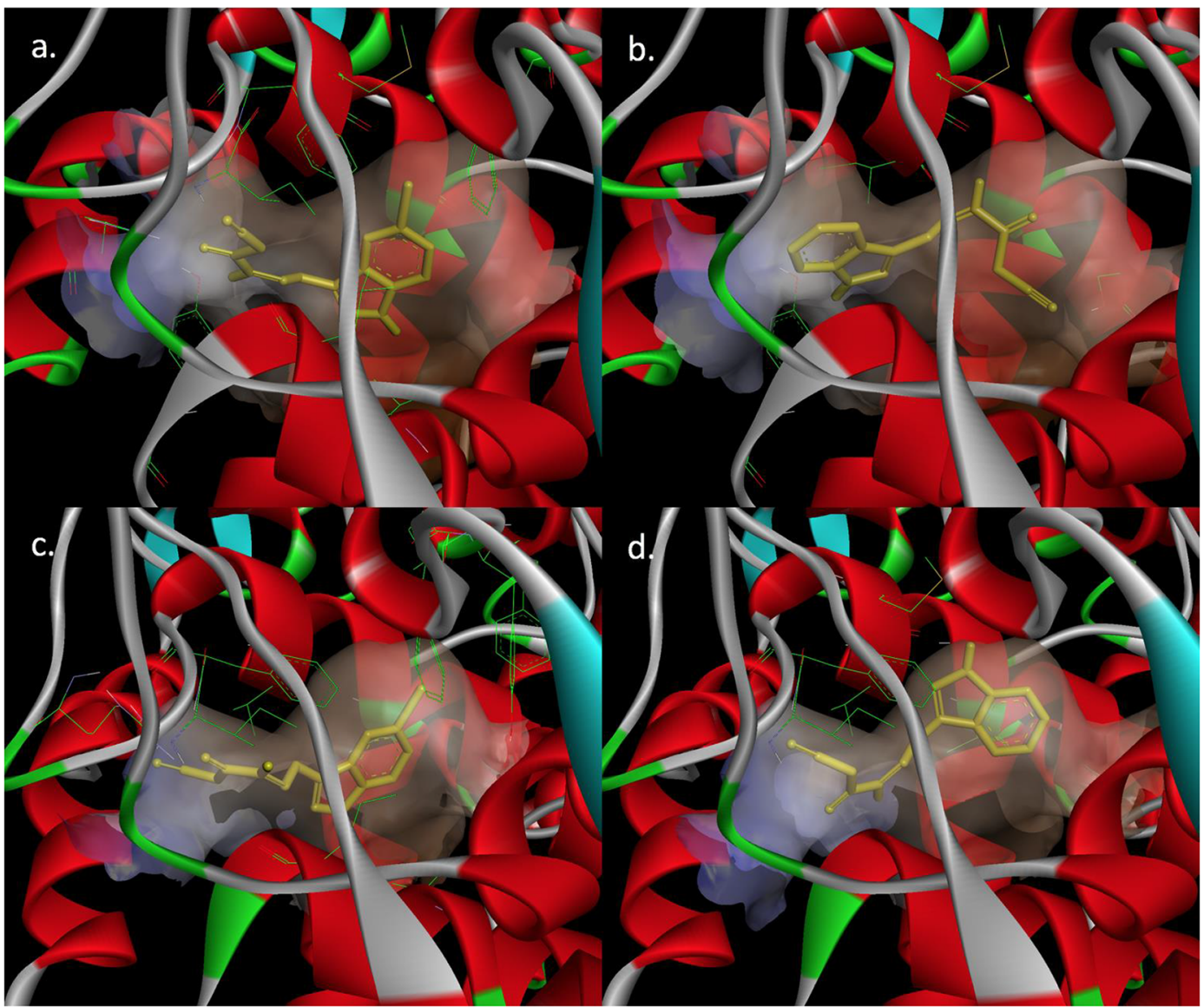

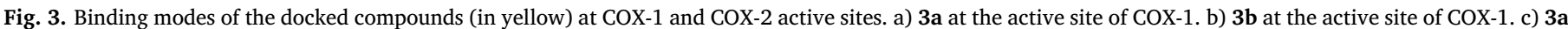

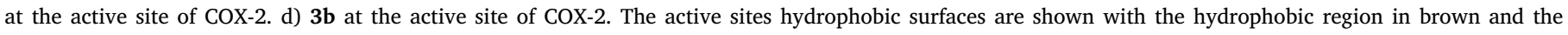
hydrophilic region in blue.

conformation where the indole ring is pointed to the hydrophilic sidepocket of the active site via a carbon-hydrogen bond to Tyr355 and PiSigma interactions with Ile523. This compound also makes two hydrogen bonds with the active site (Ser530 with the nitrile and Met522 with the amide hydrogen). Compound 3a, on the other hand, maintains a similar conformation when compared to the COX-2 active site. The bromine substituted indole ring is pointed to the hydrophobic pocket of the active site and interacts with Ala527 and Val349 via Pi-Sigma interactions and Leu352 via Pi-Alkyl interactions. The nitrile makes one hydrogen bond to Ile517.

The conformation of compound $\mathbf{3 b}$ at the COX-1 active site (compared to 3a) may avoid the effective ligand-receptor interactions, which could lead to the different activities of these compounds towards COX-1 and the COX-2 selectivity of $\mathbf{3 b}$.

\subsubsection{ADMET prediction}

In silico ADMET predictions were performed to evaluate the pharmacokinetic and toxicity profiles of compounds $\mathbf{3} \mathbf{a}$ and $\mathbf{3} \mathbf{b}$. Accordingly to Lipinski's rules ${ }^{37}$, the potential drug is orally active when meets the following criteria: a) molecular weight $\leq 500 \mathrm{da}$; b) $\operatorname{LogP} \leq 5$ (or MLogP $\leq 4.15$ ); c) number of hydrogen bond acceptors $\leq 10$; d) number of hydrogen bond donors $\leq 5$. Structures $3 \mathbf{a}$ and $\mathbf{3 b}$ present $\operatorname{MLog} P<1$ and an adequate (based on Lipinski's Rules) number of hydrogen bond donors and acceptors, which suggests a good oral bioavailability (Table 4). In addition, the $\log S$ value shows that both compounds are water soluble ( $\log S$ between -4 and -2 ), a key feature to an appropriate bioavailability.

The TPSA value indicates that these molecules may have good intestinal absorption (expected for molecules with TPSA $\leq 140 \AA^{2}$ ). ${ }^{38}$ The
Caco-2 monolayer of cells is widely used as an in vitro model to predict intestinal absorption of orally administered drugs, by measuring the logarithm of the apparent permeability coefficient (log Papp, log cm $\mathrm{s}^{-1}$ ). A high absorption is expected for values of log Papp $>0.90$ $\mathrm{cm} \mathrm{s}^{-1}$. Only compound 3a had a log Papp $>0.90 .^{39}$ However, both compounds presented a high probability of absorption at the small human intestine, with values $>90 \%$.

The volume of distribution (VDss) indicates the theoretical volume that a total dose would need to be uniformly distributed in the plasma at the same concentration observed in blood plasma. High values of VDss ( $\log$ VDss $>0.45$ ) indicate the drug will be distributed in tissue rather than plasma. VDss value is considered low when log VDss $<-0.15 .{ }^{39}$ Compounds $\mathbf{3} \mathbf{a}$ and $\mathbf{3 b}$ showed intermediate values of VDss, and should have an adequate plasma distribution profile, with a fraction of the unbound drug of 0.305 and 0.325 , respectively. These values indicate that the drug can be well distributed and present a significative unbound (and readily avaliable to interact with the target) fraction at the plasma.

Drug clearance occurs primarily as a combination of renal and hepatic clearance and is related to the drug bioavailability. A drug with a high total clearance value will present a fast excretion process. Compounds $3 \mathbf{a}$ and $\mathbf{3 b}$ present total clearance values of 0.188 and 0.94 , respectively.

The toxicity risk predictor algorithm used by the Osiris Datawarrior predicts the probability of tumorigenic, mutagenic, reproductive or irritant effects that may be caused by drugs. When structures $\mathbf{3 a}$ and $\mathbf{3 b}$ were evaluated, it was found that none of these effects were present. 
Table 4

In-Silico Pharmacokinetic data estimated at SwissADME or pkCSM webservices.

\begin{tabular}{|c|c|c|c|c|c|c|c|c|}
\hline Compound & $\log P^{\mathrm{a}}$ & $\log S^{\mathrm{b}}$ & TPSA $\left(\AA^{2}\right)^{\mathrm{c}}$ & Caco-2 permeability (log Papp; $\log \mathrm{cm} / \mathrm{s})^{\mathrm{d}}$ & Int. Abs. $(\%)^{\mathrm{e}}$ & VDss $(\log \mathrm{L} / \mathrm{kg})^{\mathrm{f}}$ & Fract. Unb. ${ }^{\mathrm{g}}$ & Total Clearance $(\log \mathrm{ml} / \mathrm{min} / \mathrm{kg})^{\mathrm{h}}$ \\
\hline 3a & 0.93 & -3.20 & 81.04 & 1.012 & 90.33 & -0.009 & 0.305 & 0.188 \\
\hline $3 b$ & 0.25 & -2.49 & 81.04 & 0.812 & 91.90 & 0.018 & 0.325 & 0.94 \\
\hline
\end{tabular}

a SwissADME Moriguchi log of octanol-water partition coefficient.

b SwissADME Ali log of aqueous solubility.

c SwissADME calculation of Topological Polar Surface Area (TPSA).

d pkCSM prediction of Caco-2 cell permeability as estimation of absorption at human intestinal mucosa.

e pkCSM prediction of the proportion of compound absorption though the human small intestine.

${ }^{f}$ pkCSM prediction of the log of steady state volume of distribution (VDss).

$\mathrm{g}$ pkCSM prediction of compound fraction unbound in plasma (not bound to serum proteins).

$\mathrm{h}$ pkCSM prediction of the log of total drug clearance.

\section{Conclusions}

In this study, novel compounds containing $N$-acylhydrazone and indole moieties were obtained and their anti-inflammatory activity were succesfuly evaluated. The lymphocyte proliferation inhibition tests indicate these compounds as potential agents to act in the cellular phase of inflammation proccess. In vivo assays corroborated the in vitro results, where the maximum suppression values of mouse paw edema were observed in the late phase (cellular phase). Additionally, findings regarding the inhibition of COX-1 and COX-2 indicate $\mathbf{3 b}$ as a selective COX-2 inhibitor, but less potent when compared to celecoxib. Moreover, immunological assays reinforce and indicated the higher anti-inflammatory profile promoted by compound $\mathbf{3 b}$. The molecular docking results suggested compounds $3 \mathbf{a}$ and $\mathbf{3 b}$ interacting with the active site of COX-2 in related conformations but with different arrangements at the active site of COX-1. One may associate this with the observed COX inhibition selectivity of compound $\mathbf{3 b}$. Thus, the anti-inflammatory results and ADMET predicted values of compound $\mathbf{3 a}$ and $\mathbf{3 b}$ present a well-balanced profile between pharmacodynamics and pharmacokinetics, which justifies the use of these derivatives - mainly $\mathbf{3 b}$, a selective COX-2 inhibitor - as lead compounds in the development of anti-inflammatory drugs.

\section{Experimental section}

\subsection{Chemistry section}

All reagents used in this study were commercially available (SigmaAldrich, Acros Organics, Vetec). The melting points were determined on Fisatom 431D (Fisatom, Brazil) apparatus and were uncorrected. IR spectra were measured on Bruker IFS-66 IR spectrophotometer (Bruker, Germany) using $\mathrm{KBr}$ pellets. NMR spectra were recorded on Bruker AMX-300 MHz (300 MHz for ${ }^{1} \mathrm{H}$ and $75 \mathrm{MHz}$ for ${ }^{13} \mathrm{C}$ ) instruments by using tetramethylsilane as an internal standard. DMSO- $d_{6}$ was purchased from Sigma-Aldrich. The chemical shifts were reported in $\delta$ units and coupling constants $(J)$ were reported in Hertz $(\mathrm{Hz})$. The multiplicities were given as s (singlet), $\mathrm{d}$ (doublet), $\mathrm{t}$ (triplet), $\mathrm{m}$ (multiplet), dd (double doublet). TLC development was conducted on $0.25 \mathrm{~mm}$ silica gel plates (Merck, silica gel $60 \mathrm{~F}_{254}$ in aluminium foil).

\subsubsection{General procedure for obtaining the compounds}

Cyanoacetohydrazide (1) $(1 \mathrm{mmol})$ was added to a solution of substituted indole-3-carboxaldehyde (2) $(1 \mathrm{mmol})$ and $3-5$ drops of acetic acid in ethanol $(10 \mathrm{~mL})^{19}$. The reaction was processed under magnetic stirring for $12 \mathrm{~h}$ at room temperature. The formed precipitate was removed under filtration and washed with distilled water then dried in desiccator under vacuum. After drying, the products (3a-j) were recrystallized from ethanol. Yields, melting points and spectroscopic data are listed below for each new compound.

4.1.1.1. 2-Cyano- $N^{\prime}$-((5-bromo-1H-indol-3-yl)methylene)acetohydrazide (3a). Compound 3a was obtained as yellow powder (88.3\%). M.p. $\left({ }^{\circ} \mathrm{C}\right)$ :
237-239. Rf (6:4 AcOEt/n-hexane): 0.45. IR (KBr): 1233.0 (NH, Ar), $1619.6(\mathrm{C}=\mathrm{N}), 1673.6(\mathrm{HN}-\mathrm{C}=\mathrm{O}), 2275.7(\mathrm{CN}), 3286.8(\mathrm{NH}) \mathrm{cm}^{-1}$. NMR ${ }^{1} \mathrm{H}\left(300 \mathrm{MHz}\right.$, DMSO-d6): $\delta 4.21\left(\mathrm{~s}, 2 \mathrm{H}, \mathrm{CH}_{2}\right), 7.32(\mathrm{~d}, 1 \mathrm{H}, J 8.7 \mathrm{~Hz}$, ArH), 7.42 (d, $1 \mathrm{H}, J 8.1 \mathrm{~Hz}, \mathrm{ArH}), 7.88$ (s, $1 \mathrm{H}, \mathrm{ArH}), 8.17$ (s, $1 \mathrm{H}, \mathrm{N}=\mathrm{CH})$, 8.23 (s, 1H, ArNCH), 11.5 (s, 1H, ArNH), 11.7 (s, 1H, NH). NMR ${ }^{13} \mathrm{C}$ (75 MHz, DMSO-d $\left.d_{6}\right): \delta 24.75\left(\mathrm{CH}_{2}\right), 111.09(\mathrm{C}, \mathrm{Ar}), 113.6(\mathrm{C}-\mathrm{Br}, \mathrm{Ar})$, 114.33 (CH, Ar), $116.62(\mathrm{CN}), 124.25$ (CH, Ar), 126.15 (C, Ar), 132.56 $(\mathrm{HC}-\mathrm{N}), 136.18(\mathrm{C}-\mathrm{N}, \mathrm{Ar}), 141.86(\mathrm{HC}=\mathrm{N}), 164.16(\mathrm{C}=\mathrm{O}) . \mathrm{HRMS} \mathrm{m} / \mathrm{z}$ $[\mathrm{M}+\mathrm{H}]^{+}$calcd for $\mathrm{C}_{12} \mathrm{H}_{9} \mathrm{BrN}_{4} \mathrm{O}$ : 303.9960; found: 303.9887 .

\subsubsection{2-Cyano- $N^{\prime}-((1 H$-indol-3-yl)methylene $)$ acetohydrazide}

(3b). Compound 3b was obtained as yellow powder (69.03\%). M.p. $\left({ }^{\circ} \mathrm{C}\right): 199-202$. Rf (6:4 AcOEt/ $n$-hexane): 0.55. IR (KBr): $1246.5(\mathrm{NH}$, Ar), $1620.2(\mathrm{C}=\mathrm{N}), 1670.5(\mathrm{HN}-\mathrm{C}=\mathrm{O}), 2275.7(\mathrm{CN}), 3300.8(\mathrm{NH})$ $\mathrm{cm}^{-1}$. NMR ${ }^{1} \mathrm{H}\left(300 \mathrm{MHz}\right.$, DMSO- $\left.d_{6}\right): \delta 4.22\left(\mathrm{~s}, 2 \mathrm{H}, \mathrm{CH}_{2}\right), 7.15(\mathrm{t}, 1 \mathrm{H}, J$ $7.35 \mathrm{~Hz}, \mathrm{ArH}), 7.2$ (t, $1 \mathrm{H}, J 7.35 \mathrm{~Hz}, \mathrm{ArH}), 7.44$ (d, $1 \mathrm{H}, J 7.2 \mathrm{~Hz}, \mathrm{ArH})$, 7.81 (s, $1 \mathrm{H}, \mathrm{ArNCH}), 8.12$ (d, $1 \mathrm{H}, J 7.5 \mathrm{~Hz}, \mathrm{ArH}), 8.19$ (s, $1 \mathrm{H}, \mathrm{N}=\mathrm{CH}$ ), 11.46 (s, $1 \mathrm{H}, \mathrm{NH}), 11.58$ (s, $1 \mathrm{H}, \mathrm{ArNH}) . \mathrm{NMR}{ }^{13} \mathrm{C}$ (75 MHz, DMSO- $\left.d_{6}\right): \delta$ $24.44\left(\mathrm{CH}_{2}\right), 111.83(\mathrm{CH}, \mathrm{Ar}), 111.13(\mathrm{C}, \mathrm{Ar}), 116.32(\mathrm{CN}), 120.64(\mathrm{CH}$, Ar), 121.86 (CH, Ar), 122.67 (CH, Ar), 123.94 (C, Ar), 130.93 (HC-N), $137.08(\mathrm{C}-\mathrm{N}, \mathrm{Ar}), 141.95(\mathrm{HC}=\mathrm{N}), 163.78(\mathrm{C}=\mathrm{O})$. HRMS $\mathrm{m} / \mathrm{z}[\mathrm{M}$ $+\mathrm{H}]^{+}$calcd for $\mathrm{C}_{12} \mathrm{H}_{10} \mathrm{~N}_{4} \mathrm{O}$ : 226.0855; found: 226.0943 .

4.1.1.3. 2-Cyano- $N^{\prime}$-((5-methyl-1H-indol-3-yl)methylene)acetohydrazide (3c). Compound $3 \mathrm{c}$ was obtained as white powder $(61.45 \%)$. M.p. $\left({ }^{\circ} \mathrm{C}\right)$ : 213-216. Rf (6:4 AcOEt/n-hexane): 0.51. IR (KBr): 1245.5 (NH, Ar), $1614.5(\mathrm{C}=\mathrm{N}), 1677.1(\mathrm{HN}-\mathrm{C}=\mathrm{O}), 2269.3(\mathrm{CN}), 3345.7(\mathrm{NH}) \mathrm{cm}^{-1}$. NMR ${ }^{1} \mathrm{H}\left(300 \mathrm{MHz}\right.$, DMSO- $\left.d_{6}\right): \delta 2.43\left(\mathrm{~s}, 3 \mathrm{H}, \mathrm{CH}_{3}\right), 4.21\left(\mathrm{~s}, 2 \mathrm{H}, \mathrm{CH}_{2}\right)$, 7.02 (d, $1 \mathrm{H}, J 8.4 \mathrm{~Hz}, \operatorname{ArH}), 7.31$ (d, $1 \mathrm{H}, J 8.1 \mathrm{~Hz}, \mathrm{ArH}), 7.75$ (s, $1 \mathrm{H}$, ArNCH), 7.9 (s, 1H, ArH), $8.16(\mathrm{~s}, 1 \mathrm{H}, \mathrm{N}=\mathrm{CH}), 11.43(\mathrm{~s}, 1 \mathrm{H}, \mathrm{ArNH})$, $11.46(\mathrm{~s}, 1 \mathrm{H}, \mathrm{NH}) . \mathrm{NMR}{ }^{13} \mathrm{C}\left(75 \mathrm{MHz}, \mathrm{DMSO}-d_{6}\right): \delta 21.37\left(\mathrm{CH}_{3}\right), 24.42$ $\left(\mathrm{CH}_{2}\right), 110.66$ (C, Ar), $111.52(\mathrm{CH}, \mathrm{Ar}), 116.36(\mathrm{CN}), 121.51(\mathrm{CH}, \mathrm{Ar})$, 124.16 (CH, Ar), 124.21 (C, Ar), $129.16\left(\mathrm{C}-\mathrm{CH}_{3}, \mathrm{Ar}\right), 130.92(\mathrm{HC}-\mathrm{N})$, $135.4(\mathrm{C}-\mathrm{N}, \mathrm{Ar}), 142.13(\mathrm{HC}=\mathrm{N}), 163.69(\mathrm{C}=\mathrm{O})$. HRMS $\mathrm{m} / \mathrm{z}[\mathrm{M}$ $+\mathrm{H}]^{+}$calcd for $\mathrm{C}_{13} \mathrm{H}_{12} \mathrm{~N}_{4} \mathrm{O}$ : 240.1011; found: 240.1096.

4.1.1.4. 2-Cyano- $N^{\prime}$-((4-nitro-1H-indol-3-yl)methylene)acetohydrazide (3d). Compound 3d was obtained as orange powder (88.3\%). M.p. $\left({ }^{\circ} \mathrm{C}\right)$ : 222-225. Rf (6:4 AcOEt/n-hexane): 0.42. IR (KBr): 1280.9 (NH, Ar), 1588.9 $(\mathrm{C}=\mathrm{N}), 1675.6(\mathrm{HN}-\mathrm{C}=\mathrm{O}), 2259.6(\mathrm{CN}), 3268.4(\mathrm{NH}) \mathrm{cm}^{-1} . \mathrm{NMR}^{1} \mathrm{H}$ (300 MHz, DMSO- $d_{6}$ ): $\delta 4.10$ (s, $2 \mathrm{H}, \mathrm{CH}_{2}$ ), 7.3 (d, $\left.1 \mathrm{H}, J 8.4 \mathrm{~Hz}, \mathrm{ArH}\right), 7.4$ (d, $1 \mathrm{H}, J 7.5 \mathrm{~Hz}, \mathrm{ArH}), 7.87$ (t, $1 \mathrm{H}, J 7.95 \mathrm{~Hz}, \mathrm{ArH}), 8.2$ (s, 1H, ArNCH), 8.38 (s, $1 \mathrm{H}, \mathrm{N}=\mathrm{CH}), 11.6(\mathrm{~s}, 1 \mathrm{H}, \mathrm{ArNH}), 12.48(\mathrm{~s}, 1 \mathrm{H}, \mathrm{NH}) . \mathrm{NMR}{ }^{13} \mathrm{C}(75 \mathrm{MHz}$, DMSO- $\left.d_{6}\right): \delta 23.88\left(\mathrm{CH}_{2}\right), 109.79(\mathrm{C}, \mathrm{Ar}), 116.18(\mathrm{CN}), 117.12(\mathrm{C}, \mathrm{Ar})$, 117.77 (CH, Ar), 118.66 (CH, Ar), 121,36 (CH, Ar), $132.23(\mathrm{HC}-\mathrm{N}), 139.08$ $(\mathrm{C}-\mathrm{N}, \mathrm{Ar}), 140.99(\mathrm{HC}=\mathrm{N}), 142.1\left(\mathrm{C}-\mathrm{NO}_{2}, \mathrm{Ar}\right), 163.92(\mathrm{C}=\mathrm{O}) . \mathrm{HRMS} \mathrm{m} / \mathrm{z}$ $[\mathrm{M}+\mathrm{H}]^{+}$calcd for $\mathrm{C}_{12} \mathrm{H}_{9} \mathrm{~N}_{5} \mathrm{O}_{3}$ : 271.0705; found: 271.0966.

\subsubsection{2-Cyano- $N^{\prime}$-((5-methoxy-1H-indol-3-yl)methylene)}

acetohydrazide (3e). Compound $3 \mathbf{e}$ was obtained as yellow powder (81.8\%). M.p. $\left({ }^{\circ} \mathrm{C}\right): 212-214$. Rf (6:4 AcOEt/n-hexane): 0.42. IR (KBr): 
$1254.6(\mathrm{NH}, \mathrm{Ar}), 1620.2(\mathrm{C}=\mathrm{N}), 1672.9(\mathrm{HN}-\mathrm{C}=\mathrm{O}), 2269.3(\mathrm{CN})$, $3332.5(\mathrm{NH}) \mathrm{cm}^{-1}$. NMR ${ }^{1} \mathrm{H}\left(300 \mathrm{MHz}, \mathrm{DMSO}-d_{6}\right): \delta\left(\mathrm{s}, 3 \mathrm{H}, \mathrm{CH}_{3}\right), 4.21$ (s, $\left.2 \mathrm{H}, \mathrm{CH}_{2}\right), 6.83(\mathrm{~d}, 1 \mathrm{H}, J 8.7 \mathrm{~Hz}, \mathrm{ArH}), 7.33(\mathrm{~d}, 1 \mathrm{H}, J 8.7 \mathrm{~Hz}, \mathrm{ArH})$, 7.61 (s, 1H, ArH), 7.75 (s, 1H, ArNCH), 8.17 (s, 1H, N=CH), 11.46 (s, $2 \mathrm{H}, \mathrm{ArNH}$ e $\mathrm{NH})$. NMR ${ }^{13} \mathrm{C}\left(75 \mathrm{MHz}, \mathrm{DMSO}-d_{6}\right): \delta 24.78\left(\mathrm{CH}_{2}\right), 55.53$ $\left(\mathrm{CH}_{3}\right), 103.81$ (CH, Ar), 111.33 (C, Ar), $113.11(\mathrm{CH}, \mathrm{Ar}), 116.76(\mathrm{CN})$, 124.91 (C, Ar), 131.63 (HC-N, Ar), 132.31 (C-N, Ar), 142.46 (HC= $\mathrm{N}), 154.92\left(\mathrm{C}-\mathrm{OCH}_{3}, \mathrm{Ar}\right), 164.07(\mathrm{C}=\mathrm{O})$. HRMS $m / z[\mathrm{M}+\mathrm{H}]^{+}$calcd for $\mathrm{C}_{13} \mathrm{H}_{12} \mathrm{~N}_{4} \mathrm{O}_{2}$ : 256.0960; found: 256.0876 .

4.1.1.6. 2-Cyano- $N^{\prime}-((1 H$-benzo[g]indol-3-yl)methylene)acetohydrazide (3f). Compound 3f was obtained as yellow powder (97.8\%). M.p. $\left({ }^{\circ} \mathrm{C}\right)$ : 240-242. Rf (6:4 AcOEt/n-hexane): 0.36. IR (KBr): $1221.2(\mathrm{NH}, \mathrm{Ar})$, $1621.4(\mathrm{C}=\mathrm{N}), 1671.5(\mathrm{HN}-\mathrm{C}=\mathrm{O}), 2262.8(\mathrm{CN}), 3316.0(\mathrm{NH}) \mathrm{cm}^{-1}$. NMR ${ }^{1} \mathrm{H}\left(300 \mathrm{MHz}\right.$, DMSO-d $\left.\mathrm{d}_{6}\right): \delta 4.28\left(\mathrm{~s}, 2 \mathrm{H}, \mathrm{CH}_{2}\right), 7.48(\mathrm{~d}, 1 \mathrm{H}, J$ $8.1 \mathrm{~Hz}, \mathrm{ArH}), 7.59$ (t, $2 \mathrm{H}, J 8.85 \mathrm{~Hz}, \mathrm{ArH}), 7.91$ (s, 1H, ArNCH), 7.97 (d, $1 \mathrm{H}, J 8.1 \mathrm{~Hz}, \operatorname{ArH}), 8.25$ (d, $1 \mathrm{H}, J 9.0 \mathrm{~Hz}, \operatorname{ArH}), 8.27(\mathrm{~s}, 1 \mathrm{H}, \mathrm{N}=\mathrm{CH})$, 8.40 (d, 1H, J 8.7 Hz, ArH), 11.54 (s, 1H, ArNH), 12.49 (s, 1H, NH). NMR ${ }^{13} \mathrm{C}\left(75 \mathrm{MHz}, \mathrm{DMSO}-d_{6}\right): \delta 24.51\left(\mathrm{CH}_{2}\right), 112.76(\mathrm{C}, \mathrm{Ar}), 116.35$ (CN), 120.03 (C, Ar), 120.79 (CH, Ar), 121.47 (CH, Ar), 121.73 (C, Ar), 124.30 (CH, Ar), 125.65 (HC-N, Ar), 128.65 (CH, Ar), 128.59 (CH, Ar), $128.39(\mathrm{CH}, \mathrm{Ar}), 131.86(\mathrm{C}-\mathrm{N}, \mathrm{Ar}), 141,96(\mathrm{HC}=\mathrm{N}), 163.89(\mathrm{C}=\mathrm{O})$. HRMS $m / z[\mathrm{M}+\mathrm{H}]^{+}$calcd for $\mathrm{C}_{16} \mathrm{H}_{12} \mathrm{~N}_{4} \mathrm{O}$ : 276.1011; found: 276.1239.

4.1.1.7. 2-Cyano-N'-((7-methyl-1H-indol-3-yl)methylene)acetohydrazide (3g). Compound $\mathbf{3} \mathrm{g}$ was obtained as yellow powder (86.6\%). M.p. $\left({ }^{\circ} \mathrm{C}\right): 219-221 . \mathrm{Rf}(6: 4 \mathrm{AcOEt} / n$-hexane): 0.31. IR $(\mathrm{KBr}): 1236.9(\mathrm{NH}$, Ar), $1618.7(\mathrm{C}=\mathrm{N}), 1674.0(\mathrm{HN}-\mathrm{C}=\mathrm{O}), 2275.7(\mathrm{CN}), 3324.3(\mathrm{NH})$ $\mathrm{cm}^{-1}$. NMR ${ }^{1} \mathrm{H}\left(300 \mathrm{MHz}, \mathrm{DMSO}-d_{6}\right): \delta 4.28\left(\mathrm{~s}, 3 \mathrm{H}, \mathrm{CH}_{3}\right), 4.23(\mathrm{~s}, 2 \mathrm{H}$, $\mathrm{CH}_{2}$ ), 7.02 (d, $\left.1 \mathrm{H}, J 7.2 \mathrm{~Hz}, \mathrm{ArH}\right), 7.08$ (t, $\left.1 \mathrm{H}, J 7.35 \mathrm{~Hz}, \mathrm{ArH}\right), 7.83$ (s, $1 \mathrm{H}, \mathrm{ArNCH}), 7.98$ (d, 1H, J 7.5 Hz, ArH), 8.22 (s, 1H, N=CH), 11.48 (s, $1 \mathrm{H}, \mathrm{ArNH}), 11.58$ (s, $1 \mathrm{H}, \mathrm{NH}) . \mathrm{NMR}{ }^{13} \mathrm{C}\left(75 \mathrm{MHz}, \mathrm{DMSO}-d_{6}\right): \delta 24.51$ $\left(\mathrm{CH}_{3}\right), 24.84\left(\mathrm{CH}_{2}\right), 111.99(\mathrm{C}, \mathrm{Ar}), 116.73(\mathrm{CN}), 119.86(\mathrm{CH}, \mathrm{Ar})$, 121.27 ( $\mathrm{CH}, \mathrm{Ar}), 121.42$ (C- $\left.\mathrm{CH}_{3}, \mathrm{Ar}\right), 123.66$ (CH, Ar), 124.15 (C, Ar), $131.09(\mathrm{HC}-\mathrm{N}, \mathrm{Ar}), 136.99(\mathrm{C}-\mathrm{N}, \mathrm{Ar}), 142.48(\mathrm{HC}=\mathrm{N}), 164.18(\mathrm{C}=$ O). HRMS $m / z[\mathrm{M}+\mathrm{H}]^{+}$calcd for $\mathrm{C}_{13} \mathrm{H}_{12} \mathrm{~N}_{4} \mathrm{O}$ : 240.1011; found: 240.0987 .

4.1.1.8. 2-Cyano- $N^{\prime}$-((5-cyano-1H-indol-3-yl)methylene)acetohydrazide (3h). Compound $3 \mathrm{~h}$ was obtained as yellow powder (98\%). M.p. $\left({ }^{\circ} \mathrm{C}\right)$ : 247-249. Rf (6:4 AcOEt/n-hexane): 0.22. IR (KBr): 1247.6 (NH, Ar), $1621.8(\mathrm{C}=\mathrm{N}), 1677.3(\mathrm{HN}-\mathrm{C}=\mathrm{O}), 2223.8(\mathrm{CN}), 3295.8(\mathrm{NH}) \mathrm{cm}^{-1}$. NMR ${ }^{1} \mathrm{H}\left(300 \mathrm{MHz}\right.$, DMSO-d $\left.\mathrm{d}_{6}\right): \delta 4.30\left(\mathrm{~s}, 2 \mathrm{H}, \mathrm{CH}_{2}\right), 7.55$ (d, $1 \mathrm{H}, J$ $8.1 \mathrm{~Hz}, \mathrm{ArH}$ ), 7.61 (d, $1 \mathrm{H}, J 8.1 \mathrm{~Hz}, \operatorname{ArH}$ ), 8.02 (s, 1H, ArNCH), 8.19 (s, $1 \mathrm{H}, \mathrm{ArH}), 8.51$ (s, 1H, N=CH), 11.56 (s, 1H, ArNH), 12.08 (s, 1H, NH). NMR ${ }^{13} \mathrm{C}\left(75 \mathrm{MHz}\right.$, DMSO-d $\left.\mathrm{d}_{6}\right): \delta 25.00\left(\mathrm{CH}_{2}\right), 103.28(\mathrm{C}-\mathrm{C}=\mathrm{N}, \mathrm{Ar})$, 112.26 (C, Ar), 113.68 (CH, Ar), 116.81 (CN), 120.92 (CN), 124.03 (C, $\mathrm{Ar}), 126.07(\mathrm{CH}, \mathrm{Ar}), 127.40(\mathrm{CH}, \mathrm{Ar}), 133.45(\mathrm{HC}-\mathrm{N}), 139.26(\mathrm{C}-\mathrm{N}$, $\mathrm{Ar}), 141.39(\mathrm{HC}=\mathrm{N}), 164.49(\mathrm{C}=\mathrm{O})$. HRMS $m / z[\mathrm{M}+\mathrm{H}]^{+}$calcd for $\mathrm{C}_{13} \mathrm{H}_{9} \mathrm{~N}_{5} \mathrm{O}$ : 251.0807; found: 251.0780.

\subsubsection{2-Cyano- $N^{\prime}-((1 H$-pyrrolo[2,3-b]pyridin-3-yl)methylene)}

acetohydrazide (3i). Compound $\mathbf{3 i}$ was obtained as white powder (79.1\%). M.p. $\left({ }^{\circ} \mathrm{C}\right): 244-246$. Rf (6:4 AcOEt $/ n$-hexane): 0.38. IR $(\mathrm{KBr}): 1260.1(\mathrm{NH}, \mathrm{Ar}), 1580.4(\mathrm{C}=\mathrm{N}), 1667.5(\mathrm{HN}-\mathrm{C}=\mathrm{O}), 2259.6$ (CN), $3145.3(\mathrm{NH}) \mathrm{cm}^{-1}$. NMR ${ }^{1} \mathrm{H}\left(300 \mathrm{MHz}, \mathrm{DMSO}-d_{6}\right): \delta 4.25(\mathrm{~s}, 2 \mathrm{H}$, $\mathrm{CH}_{2}$ ), 7.21 (t, $\left.1 \mathrm{H}, J 7.2 \mathrm{~Hz}, \operatorname{ArH}\right), 7.96$ (s, $1 \mathrm{H}, \operatorname{ArNCH}$ ), 8.16 (s, $1 \mathrm{H}$, $\mathrm{N}=\mathrm{CH}), 8.31$ (d, $1 \mathrm{H}, J 6.9 \mathrm{~Hz}, \mathrm{ArH}), 8.47$ (d, $1 \mathrm{H}, J 7.5 \mathrm{~Hz}, \mathrm{ArH}), 11.58$ (s, $1 \mathrm{H}, \mathrm{ArNH}), 12.07$ (s, $1 \mathrm{H}, \mathrm{NH})$. NMR ${ }^{13} \mathrm{C}(75 \mathrm{MHz}$, DMSO-d 6 ): $\delta 24.92$ $\left(\mathrm{CH}_{2}\right), 110.42$ (C, Ar), 110.47 (C, Ar), $116.73(\mathrm{CN}), 117.38(\mathrm{CH}, \mathrm{Ar})$, 129.29 (HC-N, Ar), 131.42 (CH, Ar), $141.83(\mathrm{CH}, \mathrm{Ar}), 144,44(\mathrm{HC}=$ $\mathrm{N}), 149.74(\mathrm{C}-\mathrm{N}, \mathrm{Ar}), 164.41(\mathrm{C}=\mathrm{O})$. HRMS $m / z[\mathrm{M}+\mathrm{H}]^{+}$calcd for $\mathrm{C}_{11} \mathrm{H}_{9} \mathrm{~N}_{5} \mathrm{O}$ : 227.0807; found: 227.0836.

4.1.1.10. 2-Cyano- $N^{\prime}$-((5-chloro-1H-indol-3-yl)methylene)acetohydrazide (3j). Compound $3 \mathbf{j}$ was obtained as yellow powder (98.2\%). M.p. $\left({ }^{\circ} \mathrm{C}\right)$ :
241-243. Rf (6:4 AcOEt/n-hexane): 0.40. IR (KBr): 1231.8 (NH, Ar), $1618.3(\mathrm{C}=\mathrm{N}), 1684.5(\mathrm{HN}-\mathrm{C}=\mathrm{O}), 2279.1(\mathrm{CN}), 3302.0(\mathrm{NH}) \mathrm{cm}^{-1}$. NMR ${ }^{1} \mathrm{H}\left(300 \mathrm{MHz}\right.$, DMSO- $\left.d_{6}\right): \delta 4.22\left(\mathrm{~s}, 2 \mathrm{H}, \mathrm{CH}_{2}\right), 7.21(\mathrm{~d}, 1 \mathrm{H}, J$ $8.7 \mathrm{~Hz}, \mathrm{ArH}$ ), 7.46 (d, 1H, $J 8.7 \mathrm{~Hz}, \mathrm{ArH}), 7.90$ (s, 1H, ArNCH), 8.07 (s, $1 \mathrm{H}, \mathrm{ArH}), 8.16$ (s, $1 \mathrm{H}, \mathrm{N}=\mathrm{CH}), 11.50(\mathrm{~s}, 1 \mathrm{H}, \mathrm{ArNH}), 11.76(\mathrm{~s}, 1 \mathrm{H}, \mathrm{NH})$. NMR ${ }^{13} \mathrm{C}\left(75 \mathrm{MHz}\right.$, DMSO- $\left.d_{6}\right): \delta 24.36\left(\mathrm{CH}_{2}\right), 110.78(\mathrm{C}, \mathrm{Ar}), 113.46$ (CH, Ar), $116.23(\mathrm{C}=\mathrm{N}), 120.80(\mathrm{CH}, \mathrm{Ar}), 122.68(\mathrm{CH}, \mathrm{Ar}), 124.0(\mathrm{C}$, Ar), 125.21 (C-Cl, Ar), $132.36(\mathrm{HC}-\mathrm{N}, \mathrm{Ar}), 135.51$ (C-N, Ar), 141.44 $(\mathrm{HC}=\mathrm{N}), 163.76(\mathrm{C}=\mathrm{O})$. HRMS $\mathrm{m} / z[\mathrm{M}+\mathrm{H}]^{+}$calcd for $\mathrm{C}_{12} \mathrm{H}_{9} \mathrm{ClN}_{4} \mathrm{O}$ : 260.0465; found: 260.0295 .

\subsection{Biological section}

\subsubsection{In vitro studies}

4.2.1.1. J774 macrophages cytotoxicity. J774 macrophages $\left(1 \times 10^{4}\right.$ cells/well) were distributed in 96-well plate in DMEM medium. Each compound was solubilized in $1 \%$ DMSO. As a positive control, gentian violet was tested, whereas as a negative control, the wells received only DMEM and DMSO medium. The plate was then cultured for $72 \mathrm{~h}$, at $37^{\circ} \mathrm{C}$ and $5 \% \mathrm{CO}_{2}$. Then $20 \mu \mathrm{L}$ of AlamarBlue was added in each well and the plate incubated for an additional $4 \mathrm{~h}$. The plate was read on the plate reader at 570 and $600 \mathrm{~nm}$. The $\mathrm{CC}_{50}$ values were calculated on the GraphPad Prism version 5.0, San Diego California, USA. ${ }^{40}$

4.2.1.2. Lymphoproliferation assay. Splenocytes of BALB/c mice $\left(5 \times 10^{6}\right.$ cells/well, $\left.200 \mu \mathrm{L}\right)$ were cultured in DMEM medium and 96well plates in triplicates, in the presence or not of concanavalin A $\left(2 \mu \mathrm{gL}^{-1}\right)$ and also in the presence or absence of the analyzed compounds. After $48 \mathrm{~h}$ of incubation, at $37^{\circ} \mathrm{C}$ and $5 \% \mathrm{CO}_{2}, 1 \mu \mathrm{Ci}$ of [methyl $-{ }^{3} \mathrm{H}$ ] thymidine was added to the cultures, starting a new 12-h incubation period. After this period, the cells were collected for quantification of proliferation by thymidine uptake determination. The percent inhibition was determined by relating the thymidine incorporation by the cultures treated with the evaluated compounds and the thymidine incorporation by the control cultures. Dexamethasone was used as a positive control. ${ }^{41}$

4.2.1.3. COX-1 and COX-2 inhibition assay. The screen for COX-1 and COX-2 inhibitory activity was performed according to Ayaoub et al. (2010). ${ }^{42}$ Briefly, all positive compounds and controls (indomethacin and celocoxib) were solubilized in DMSO and assayed in triplicate at $25 \mu \mathrm{M}$ concentration. COX-1 or COX-2 (Sigma-Aldrich) were added in $180 \mu \mathrm{L}$ of the assay buffer containing $5 \mathrm{mM}$ hematin (Sigma-Aldrich), $100 \mathrm{mM}$ Tris-HCl buffer, $\mathrm{pH}$ 8.0. After addition of the test compound or positive control $(10 \mu \mathrm{L})$, the reaction mixture was incubated for $5 \mathrm{~min}$ at room temperature. The reaction was started by the addition of $5 \mu \mathrm{L}$ of arachidonic acid solution (Sigma-Aldrich) dissolved in methanol and $\mathrm{N}, \mathrm{N}, \mathrm{N}^{\prime}, \mathrm{N}^{\prime}$-Tetramethyl-p-phenylenediamine dihydrochloride (TMPD). After incubation for $1 \mathrm{~h}$, the reaction mixture had its absorbance measured at $610 \mathrm{~nm}$. Compounds which inhibited $50 \%$ of COX-1 or 2 activity had its IC $_{50}$ values calculated by using ORIGIN 8.0 software (OriginLab Corporation).

\subsubsection{In vitro immunological studies}

4.2.1.4.1. Cultures with mice splenocytes. Animals used in immunological assays were mice female BALB/c (6-8 weeks old; 5 animals) raised and maintained at the animal facilities of the Keizo Asami Immunopathology Laboratory - LIKA located in Federal University of Pernambuco, Brazil. Mice were kept under standard laboratory conditions $\left(20-22^{\circ} \mathrm{C}\right.$ and $12 \mathrm{~h}$ day and night cycle) with free access to standard diet (Labina/Purina, Campinas, Brazil) and water. All experimental procedures were performed according to the Ethics Committee of Animal Use (CEUA) of Federal University of Pernambuco (protocol number: 0048/2016). After the inoculation of $1 \mathrm{mg}$ of anesthetic, and euthanasia of the animals by displacement of 
vertebra, and spleen of each mouse was removed aseptically and placed in a Falcon tube containing RPMI 1640 with fetal calf serum (complete medium). In a vertical flow, each spleen was transferred to a petri dish where they were soaked. The cell suspensions obtained from each spleen were transferred to Falcon tubes containing approximately $10 \mathrm{~mL}$ of incomplete medium. Spleen homogenates were overlaid onto Ficoll-Paque ${ }^{\mathrm{TM}}$ PLUS layer, with the density adjusted to $1.076 \mathrm{~g} /$ $\mathrm{mL}$, and centrifuged at $1000 \mathrm{~g}$ at room temperature for $25 \mathrm{~min}$. The interface cell layer containing immune cells was recovered by Pasteur pipette, washed twice in phosphate-buffered saline (PBS) and centrifuged twice at $500 \mathrm{~g}$ for $10 \mathrm{~min}$. Cells were counted in a Neubauer chamber, and cell viability was determined by the trypan blue exclusion method. Cells were only used when viability was $>98 \%$. Cells were cultured in plates ( 24 wells) with compound $\mathbf{3 b}$ at $11 \mu \mathrm{M}$ for 24 and $48 \mathrm{~h}$.

4.2.1.4.2. Investigation of immunostimulation promoted by compound 3b. Supernatant by culture of splenocytes stimulated with compound 3b were used for measure cytokines and nitric oxide release by these immune cells. Cultures were treated with $11 \mu \mathrm{M}$ of the compound and after 24 and $48 \mathrm{~h}$ supernatants were collected to performe the assays. Cytokine assessment was carried out using human Th1/Th2 cytokine kit II (BD Bioscience, San Jose, CA, USA) for simultaneous detection of six cytokines IL-2, -IL-4, IL-6, IL-10, tumor necrosis factor-alpha (TNF- $\alpha$ ), and interferon-gamma (IFN- $\gamma$ ) in culture supernatants samples. All data were acquired on FACSCalibur platform. The cytokine measurement was based on the principle of cytometric bead array (CBA) technology. Nitrite Oxide analysis was performed through colorimetric Griess method. ${ }^{43}$ NO concentration was estimated by the standard curve $(3.12-100 \mu \mathrm{mol} / \mathrm{mL})$. The reading was carried out in a microplate spectrophotometer (Thermo Scientific Multiskan FC, Waltham-USA) at $595 \mathrm{~nm}$.

\subsubsection{In vivo studies}

4.2.2.1. Animals. Experiments were conducted with Swiss Mus musculus mice $(20-35 \mathrm{~g})$ obtained from the Immunopathology Laboratory Keizo Asami (LIKA/UFPE). Animals were maintained at the biotery of the Antibiotics Departament/UFPE (Recife, Brazil), under controlled conditions $\left(22 \pm 3{ }^{\circ} \mathrm{C}\right.$ for $12 \mathrm{~h} \mathrm{light/dark} \mathrm{cycle,} \mathrm{free} \mathrm{access} \mathrm{to} \mathrm{food} \mathrm{and}$ water). All animals used for the determination of anti-inflammatory and antinociceptive activities were fasted for $4 \mathrm{~h}$ prior to the experimentation. The Animal Studies Committee of the Federal University of Pernambuco approved the experimental protocols (number 23076.017928/2010-25). The animals were treated according to the ethical principles of animal experimentation of COBEA (Brazilian College of Animal Experiments) and the norms of the National Institute of Health Guide for Care and Use of Laboratory Animals.

4.2.2.2. Acute oral toxicity. A fixed dose procedure was adopted to evaluate the acute oral toxicity of compounds $\mathbf{3} \mathbf{a}$ and $\mathbf{3 b}$ according to Organization for Economic Cooperation and Development (OECD) Guidelines for the Testing of Chemicals. ${ }^{28}$ Groups of 3 mice were dosed in a stepwise procedure using the fixed dose of $2000 \mathrm{mg} \mathrm{kg}^{-1}$. Clinical signs and conditions associated with pain, suffering and impending death are described in detail in a separate OECD Guidance Document. ${ }^{44}$ The test was conducted in duplicate.

4.2.2.3. Carrageenan-induced paw edema test in mice. Carrageenaninduced paw edema test in mices Swiss Mus musculus was used to evaluate the anti-inflammatory activity of $\mathbf{3} \mathbf{a}$ and $\mathbf{3} \mathbf{b}$. This experiment was performed on male mices as the previous report. ${ }^{29}$ Eight groups of mice $(n=8)$ were treated with DMSO\% in PBS, 3a and $\mathbf{3 b}(15,30$ and $\left.60 \mathrm{mg} \mathrm{kg}^{-1}\right)$ or indomethacin $\left(10 \mathrm{mg} \mathrm{kg}^{-1}\right)$ orally before $1 \mathrm{~h}$ of carrageenan injection. And $1 \%(\mathrm{v} / \mathrm{v})$ carrageenan $(50 \mu \mathrm{L})$ was administrated by sub-plantar injection in the right hind paws of mices. After carrageenan injection, the paw volume was measured at $1,2,3,4,5$ and $6 \mathrm{~h}$ using the plethysmometer apparatus (7140 Ugo
Basile, Italy). The increase of paw volume was measured and the inhibition of edema was calculated as the previous method.

\subsection{In silico studies}

\subsubsection{In silico ADME and molecular docking analysis}

To further strengthen the results of our in vitro studies, we also performed in silico molecular interaction analysis on compounds 3a and $\mathbf{3 b}$ and COX proteins using AutoDock4.2.6 ${ }^{45}$ in combination with the Lamarckian genetic algorithm (LGA). The ADME profiles of these compounds were also investigated with the use of SwissADME ${ }^{46}$ and pkCSM $^{47}$ webplatforms and Osiris Data Warrior software. ${ }^{48}$

\subsubsection{Molecular docking}

4.3.2.1. Ligand structure preparation. The structures of test compounds were built with Avogadro 1.2.0 $0^{49}$ software and fully optimized with PM6 $^{50}$ semiempirical method implemented in the MOPAC2016. ${ }^{51}$ The optimized ligands were then saved as pdb files. With the use of AutoDockTools-1.5.6, the non-polar hydrogens were merged with the corresponding carbons, then partial charge of atoms were calculated using the Gasteiger procedure implemented in the AutoDockTools package. The rotatable bonds of the ligands were defined, the structures were saved as pdbqt and used for docking studies.

4.3.2.2. Protein structure preparation. The crystal structures of Celecoxib co-cristallized to COX-1 (PDB ID: 3KK6) and COX-2 (PDB ID: 3LN1) were retrieved from RCSB Protein Data Bank. With the use of Dassault Systèmes BIOVIA Discovery Studio Visualizer $(v 16.1 .0 .15350)^{52}$, water molecules and other heteroatoms were removed. Then, using AutoDockTools, non-polar hydrogens were merged, and polar hydrogens added to the structure of the proteins. Kollman charges were added and the structure was saved as pdbqt for the docking studies.

4.3.2.3. Docking procedure. The 3D grid was created by the Autogrid Algorithm to generate the grid parameter file. The grid spacing was $0.0375 \mathrm{~nm}$ in each dimension, and each grid map consisted of a $70 \times 70 \times 70$ grid point. the center of the grid was set to the position of the co-crystalized ligand located at the Chain A in each case.

The Lamarckian genetic algorithm in AutoDock4.2.6 was applied to search the best conformation and orientation of the ligands. The global optimization was started with a population of 150 randomly positioned individuals with a maximum of 2,500,000 energy evaluations and a maximum of 27,000 generations. During each docking experiment, 100 runs were carried out. The resulting docking poses were analyzed using AutoDockTools and Discovery Studio Visualizer.

To validate the docking procedure, the co-crystalized ligand celecoxib was previously docked to each protein. In this case, a $126 \times 126 \times 126$ grid map was used, and 250 runs were carried out.

\subsection{Statistical analysis}

The experimental results were expressed as the mean \pm standard error (SE) and by analysis of variance (ANOVA), one-way and two-way, followed by Tukey or Bonferroni tests. P values lower than 0.05 ( $\mathrm{p}<0.05$ ) were considered as indicative of significance and represented by: ${ }^{*} \mathrm{p}<0.05,{ }^{* *} \mathrm{p}<0.01$ and ${ }^{* * *} \mathrm{p}<0.001$. The calculations were performed using the statistical software GraphPad Prism version 5.0, San Diego California, USA.

\section{Acknowledgements}

This study was supported by Brazilian agencies Fundaçao de Amparo Pesquisa do Estado de Pernambuco (FACEPE, Brazil) and Conselho Nacional de Desenvolvimento Científico e Tecnologico (CNPq). 


\section{Conflict of interest}

The authors declare that there were no competing interests.

\section{A. Supplementary data}

Supplementary data associated with this article can be found, in the online version, at https://doi.org/10.1016/j.bmc.2018.07.024.

\section{References}

1. Fullerton JN, Gilroy DW. Nat Rev Drug Discovery. 2016;15:551-567.

2. Botting J. Drug News Perspect. 2000;13:560-566.

3. Tavolari S, Bonafe M, Marini M, et al. Carcinogenesis. 2008;29:371-380.

4. Cingolani G, Panella A, Perrone MG. Eur J Med Chem. 2017;138:661-668.

5. Wallace JL. Best Pract Res Clin Gastroenterol. 2001;15:691-703.

6. Silva YKC, Augusto CV, Barbosa MLC, et al. Bioorg Med Chem. 2010;18:5007-5015.

7. Ozdemir A, Altintop MD, Turan-Zitouni G, et al. Eur J Med Chem. 2015;89:304-309.

8. Hernández P, Cabrera M, Lavaggi ML, et al. Bioorg Med Chem. 2012;20:2158-2171.

9. Tributino JLM, Duarte CD, Corrêa RS, et al. Bioorg Med Chem. 2009;17:1125-1131.

10. Singh P, Prasher P, Dhillon P, Bhatti R. Eur J Med Chem. 2015;97:104-123.

11. Pedada SR, Yarla NS, Tambade PJ, et al. Med Chem. 2016;112:289-297.

12. Guerra ASHS, Malta DJN, Laranjeira LPM, et al. Int Immunopharmacol. 2011;11:1816-1822.

13. Barbosa KP, Santos LA, Ribeiro EL, et al. Eur J Pharmacol. 2013;15:197-205.

14. Uchôa FT, Silva TG, Lima MCA, Galdino SL, Pitta IR, Dalla-Costa T. J Pharm Pharmacol. 2009;61:339-345.

15. Garcia GM, Oliveira LT, Pitta IR, et al. J Controlled Release. 2015;10:207-218.

16. Saggiomo V, Luning U. Tetrahedron Lett. 2009;50:4663-4665.

17. Nasr T, Bondock S, Youns M. Eur J Med Chem. 2014;76:539-548.

18. Al-Said MS, Bashandy MS, Al-Gasoumi SI, Ghorab MM. Eur J Med Chem. 2011;46:137-141.

19. Oliveira JF, Lima TS, Vendramini-Costa DB, et al. Eur J Med Chem. 2017; 136:305-314.

20. Cordeiro NM, Freitas RHCN, Fraga CAM, Fernandes PD. PLoS One. 2016;11:1-17.

21. Santos-Filho JM, Silva DMQ, Macedo TS, et al. Bioorg Med Chem. 2016;24:5693-5701.

22. Santos-Filho JM, Leite AC, Oliveira BG, et al. Bioorg Med Chem. 2009;17:6682-6691.
23. de la Torre SMD, Vázquez C, González-Chávez Z, et al. Bioorg Med Chem Lett. 2017;27:3403-3407.

24. Hernández P, Rojas R, Gilman RH, et al. Eur J Med Chem. 2013;59:64-74.

25. Gao J, Lauer FT, Dunaway S, Burchiel SW. Toxicol Sci. 2005;86:68-74.

26. Freitas RHCN, Cordeiro NM, Carvalho PR, et al. Chem Biol Drug Des. 2018;91:391-397.

27. Silva TF, Bispo-Júnior W, Alexandre-Moreira MS, et al. Molecules. 2015;20:3067-3088.

28. OECD Guidance Document on Acute Oral Toxicity Testing; 2002.

29. Winter CA, Risley EA, Nuss GW. Proc Soc Exp Biol Med. 1962;111:544-547.

30. Matsumoto K, Obara S, Kuroda Y, Kizu J. J Infect Chemother. 2015;21:889-891.

31. Ishola IO, Agbaje EO, Adeyemi OO, Shukla R. Pharm Biol. 2014;52:1208-1216.

32. Moldovan CM, Oniga O, Parvu A, et al. Eur J Med Chem. 2011;46:526-534

33. Melo TRF, Chelucci RC, Pires MEL, et al. Int J Mol Sci. 2014;15:5821-5837.

34. Bhookya S, Pochampally J, Valeru A, et al. Chem Biol. 2017;10:105-115.

35. Misra CS, Honnappa CG, Jitta SR, et al. Chem Biol Interact. 2016;244:71-83.

36. Voet D, Voet JG. Biochemistry. 4th ed. John Wiley \& Sons; 2011.

37. Lipinski CA, Lombardo F, Dominy BW, Feeney PJ. Adv Drug Delivery Rev. 2012;64:4-17.

38. Veber DF, Johnson SR, Cheng HY, Smith BR, Ward KW, Kopple KD. J Med Chem. 2002;45:2615-2623.

39. Lambertucci C, Marucci G, Ben DD, et al. Eur J Med Chem. 2018. https://doi.org/10 1016/j.ejmech.2018.03.067.

40. Plutín AM, Alvarez A, Mocelo R, et al. Polyhedron. 2017;132:70-77.

41. Silva DN, Souza BSF, Azevedo CM, et al. Stem Cell Res Ther. 2014;5:1-10.

42. Ayoub SS, Flower RJ, Seed M. Methods in Molecular Biology. Humana Press; 2010.

43. Ding AH, Nathan CF, Stuehr DJ. J Immunol. 1988;141:2407-2412.

44. OECD Guidance Document on the Recognition, Assessment and Use of Clinical Signs as Humane Endpoints for Experimental Animals Used in Safety Evaluation; 2000.

45. Morris MG, Huey R, Lindstrom W, et al. Comput Chem. 2009;16:2785-2791.

46. Daina A, Michielin O, Zoete V. Sci Rep. 2017;7:42717.

47. Pires DEV, Blundell TL, Ascher DB. J Med Chem. 2015;58:4066-4072.

48. Sander T, Freyss J, Von Korff M, Rufener C. J Chem Inf Model. 2015;55:460-473.

49. Hanwell MD, Curtis DE, Lonie DC, Vandermeerschd T, Zurek E, Hutchison GRJ. Cheminform. 2012;4:17

50. Stewart JJP. J Mol Model. 2007;13:1173-1213.

51. MOPAC2016, James J.P. Stewart, Stewart Computational Chemistry. CO, USA: Colorado Springs. http://OpenMOPAC.net; 2016.

52. Dassault Systèmes BIOVIA. Discovery Studio Visualizer, version 16.1.0.15350, Dassault Systèmes, San Diego; 2016 